\title{
THE ROLE OF NATIONAL ACTION PLANS IN \\ IMPLEMENTATION OF INTERNATIONAL STANDARDS IN BUSINESS AND HUMAN RIGHTS
}

Adel I. Abdullin ${ }^{1}$

Alexey A. Sinyavskiy ${ }^{2}$

Abstract: "Guiding Principles on Business and Human Rights" are the first universally recognized global international standard in the field of human rights and business. In accordance with them, transnational corporations and other enterprises are obliged to comply with the national laws of states and respect internationally recognized human rights while carrying out their business activities. On 16 June 2011, the Human Rights Council unanimously endorsed the Guidelines in its resolution 17/4, "Human Rights and Transnational Corporations and Other Enterprises," setting a universal standard for protecting human rights from the adverse effects of transnational corporations and other enterprises. However, in accordance with the doctrine of international law, corporations do not have an international legal personality and their obligations to respect human rights are only voluntary in nature, and therefore, the main obligation to ensure the protection of human rights lies with states. One of the ways to implement international standards in the field of business and human rights in practice is the development by States of National Action Plans. This paper is devoted, firstly, to a summary of the main ideas of the "Guiding Principles on Business and Human Rights" as an international legal standard in the field of human rights. Secondly, to consider the role of National Action Plans in the implementation of the Guidelines in EU countries. Thirdly, a review of existing practices for the implementation of these

1 Kazan Federal University. e-mail (electronic address for communication): Adel.Abdullin@kpfu.ru, alex.sinyavskiy95@gmail.com. Tel.: +7 9270367523.

2 Kazan Federal University. e-mail (electronic address for communication): Adel.Abdullin@kpfu.ru , alex.sinyavskiy95@gmail.com. Tel.: +7 9270367523. 
principles by EU states using National Action Plans.

Keywords: international law, corporate responsibility, international standard, human rights, national action plan, implementation, international business.

\section{Introduction}

Today it is increasingly possible to hear that enterprises violate human rights. Such violations include, for example, a violation of the right to work [23] including the use of forced labour [22], violation of freedom of association when workers are deprived of the opportunity to join unions, freedom of expression [21], violation of the right to privacy [20] when the personal data of employees and customers are sold to third parties [25; 26], violation of the right not to be discriminated against when hiring [24] due to membership in an ethnic, or religious group [17], or a caste. Another wide area of violations is the serious impact on (environmental) human rights $[18 ; 19]$, as a result of which thousands of people may die, for example, after the infamous man-made disaster at Union Carbide's chemical plant in Bhopal, in
India, during which more than 30 thousands of people died [7, 22-26]. Similar cases occur in Russia. So, on June 1, 2019, in the city of Dzerzhinsk, explosions occurred at the enterprise of the State Research Institute "Crystal" as a result of which fires broke out, 5 buildings were destroyed; residential buildings and kindergartens were damaged [35]. More than 80 people sought medical help [36].Fortunately, no one died.

In order to prevent the occurrence of such cases in the future, states of the entire world, including Russia, need to start implementing the "Guiding principles on Business and Human Rights" by developing National Action Plans.

\section{Methods}

This study uses the methodology of a concept known in Western academic literature as International Business and Human Rights. This concept is interdisciplinary in nature and is being studied in the light of a wide range of scientific disciplines, the key of which is international law. 
In carrying out this study, we used formal-logical, general scientific and particular scientific methods.

Among the formal logical methods there were used methods of analysis, synthesis and modelling. Also, historical-legal, formal-legal, comparative-legal methods were used in the work.

The normative and empirical basis of the study includes international legal standards of human rights in the field of international business, national action plans of the EU countries, cases of the ECHR, as well as other documents of international organizations (UN, EU).

\section{Results And Discussion}

Before turning to the issue of implementation, we briefly describe the international standard being implemented.

The Guiding Principles on Business and Human Rights [1] are a global, international legal standard for the protection of internationally recognized human rights in the field of business, which are understood to mean at least the rights enshrined in the International Bill of Human Rights [30; $31 ; 32]$ and the principles set forth in the
408

ILO Declaration on Fundamental Principles and Rights at Work [33]. From the point of view of the international law doctrine, they are the norms of "soft" law, are advisory in nature and, therefore, are not legally binding. They apply to all states, as well as to all corporations and commercial enterprises, regardless of their size, sector, and location, as well as the form of ownership or structure.

The "Guiding Principles on Business and Human Rights" was presented to the Human Rights Council by the Special Representative, John Ruggie, in 2011. They were based on the framework concept "Protect, Respect, and Restore Rights: Key Provisions Related to Business and Human Rights" [4], proposed by John Ruggie in 2008 containing three main principles:

1) The obligation of a state to prevent violations of human rights by a third party, including business.

2) The responsibility of corporations to respect human rights.

3) The need to ensure more effective access to remedies.

Those three principles have been embodied in the three pillars of the Guidelines: I. The state duty to protect 
human rights, II. The corporate responsibility to respect human rights, III. Access to remedies. The three pillars form a single whole, each of which can be interpreted both individually and collectively, based on the goal of enhancing the role of norms and practices related to entrepreneurial activity in the aspect of human rights, so that affected individuals and Communities could achieve tangible results in protecting their rights [1]. The guidelines contain 31 principles. Each pillar consists of foundational principles and operational principles. The foundational principles are declarative in nature: they proclaim the basic responsibilities of states and enterprises. Operational principles include practical recommendations on how to observe and ensure human rights within the framework of the duties established by the basic principles.

One of the main ways to implement the Guidelines is to develop a National Action Plan by the state. National Action Plans is a development strategy in the field of international business and human rights chosen by the state to protect individuals from the adverse effects of corporations and other
409

business enterprises on human rights and formulated by them in accordance with the UN Guidelines or other recommendations. The action plan reflects the policy of the state, and concerns the applicability of the fundamental principles to the field of business in its territory. The National Action Plans declares a promise to bring uniformity to domestic law, judicial and other practice in the field of business and human rights [5].

The two most important international guidelines that assist states in developing National Action Plans are the Guidelines for National Action Plans of the UN Working Group on Business and Human Rights [15], as well as the Toolkit for the Development, Implementation, and Review of State Commitments to Business and Human Rights Frameworks developed by Danish Institute for Human Rights [16]. The leadership of the working group presents 4 criteria that National Action Plans of States must meet [15, iii]:

1) The National Action Plan should be based on the UN Guiding Principles, the basic principles of nondiscrimination and equality, and should also reflect the existing obligations of the 
state under international human rights law to protect against adverse effects on human rights and provide access to effective remedies. In addition, National Action Plans should proclaim respect for human rights, including through measures of due concern for human rights.

2) The National Action Plan should reflect and take into account the actual (human rights violations that have already occurred) and potential (human rights violations that may occur) adverse human rights impacts. States should develop and implement realistic measures that would ensure the greatest protection of the rights of people on their territory.

3) The process of developing National Action Plans should be transparent. Stakeholders should have access to the development and updates of National Action Plans, and their opinions should be taken into account. All information on the action plan should be freely available to all interested parties throughout all stages of development.

4) The processes of National Action Plans should be regularly updated and reviewed. They must meet emerging challenges and strive for continuous development.

Within a state, all relevant ministries and departments should be involved in the development of National Action Plans, with the support of stakeholders and national human rights institutions.

Continuous updating requires regular monitoring of new challenges in the field of human rights and their timely reflection in the National Action Plans. In addition, the very format of National Action Plans presupposes interaction and international cooperation between states in order to exchange best practices and experience which can be used by any states wishing to guarantee their citizens the observance of their human rights.

From a practical point of view, A National Action Plan is an instrument for implementing the provisions of the Guidelines [15, 3]. The working group recommends dividing the process of developing National Action Plans into 5 phases: 1) Initiation 2) Assessment and consultation 3) Preparation of the initial version of the National Action Plan 4) Implementation of the National Action Plan 5) Update [16, ii]. 
During the development of their

National Action Plans, states need to identify gaps in their legal regulation using the provisions of the Guidelines, and then use them as a guide to address such gaps in their domestic law. At the same time, they must take into account the peculiarities and practice in the region on the regulation of certain legal relations in the field of human rights and business. The Working Group argues $[15,4]$ that national action plans and related processes should take into account the cultural, historical contexts of specific states and contain effective measures to prevent potential human rights violations and to eliminate the consequences of actual human rights violations by corporations and enterprises. National Action Plans must meet the challenges facing states in the areas of economics and law. [6, 3] Thus, States are given a significant share of freedom to develop and adapt measures to prevent human rights violations in their territory.

\section{Summary}

The National Action Plans received wide support from states and international organizations, and the
Guidelines themselves became the basis for the regulatory activities of the states of the entire European region. In particular, in 2011, in paragraph 4.8.2 of EU Strategy for Corporate Social Responsibility 2011-2014 [8], The European Commission called on member states to develop National Action Plans for the implementation of the Guidelines, and enterprises to respect corporate responsibility and respect for human rights. The Council of Europe has followed the example of the European Union. In 2014, the Committee of Ministers adopted the Declaration on the support of the UN Guiding Principles [9], and in 2016 the Recommendations of the Committee of Ministers to member states on business and human rights [34]. Soon, some EU members launched the process of developing National Action Plans. In 2013, the United Kingdom [14] and the Netherlands [13] published their first results, and in 2015 they were joined by Denmark [12], Finland [11] and Lithuania [10]. To date, more than 50 states have already published or are developing their National Action Plans [29]. 
The effective implementation of the Guidelines requires that all three Pillars be considered as one. However, in practice, EU member states quite selectively implement the provisions of the principles, with almost no attention to the third Pillar, access to legal remedies $[6,10]$. This practice is contrary to guidelines that should be considered "as a whole," as a result of which victims of human rights violations may be left without an effective remedy.

The European Union and the Council of Europe are absolute leaders in the dissemination of international legal standards in the field of business among member states. The dissemination of the Guidelines has led to the development of a corporate culture among all Member States. Thus, interested parties both from the side of business [27] and from the side of civil society [28] have developed their recommendations for National Action Plans.

\section{Conclusions}

The development of National Action Plans is the first step towards creating a corporate culture in society. Compliance with the principles of transparency, inclusion and non- discrimination strengthens the position of right holders and creates a space for dialogue and mutual understanding between all interested parties. Such an approach has already been implemented in practice, for example, during the adoption of the National Action Plans in Denmark, where the government conducted interviews with enterprises, representatives of civil society and "implementing organizations". Corporate culture also contributes to better protection of human rights in the field of international business.

Russia and other EAEU member states can use the experience of implementing the Guidelines, being guided by the EU and Council of Europe National Action Plans. The existing extensive practice can help the EAEU states to develop mandatory regional standards, as well as national legal acts to protect the human rights of individuals in the field of business.

\section{Acknowledgements}

The work is performed according to the Russian Government Program of Competitive Growth of Kazan Federal University. 


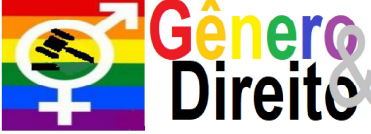

References

Human Rights Council. Guiding Principles on Business and Human Rights: Implementing the United Nations Framework for "Protection, Compliance and Legal Remedies" Report of the Special Representative of the Secretary-General for Human Rights and Transnational Corporations and Other Enterprises, John Ruggie UN Doc. A / HRC / 17/31 (March 21, 2011).

Human Rights Council. "Human rights and transnational corporations and other enterprises" Resolution 17/4 of 16 June 2011.UN Doc. A / HRC / RES / 17/4 (July 6, 2011).

Human Rights Council. "Human rights and transnational corporations and other enterprises. "Resolution 26/22 of June 27, 2014. UN Doc. A / HRC / RES / 26/22 (July 15, 2014).

Human Rights Council. "Protect, Respect, and Restore Rights: Key Provisions Related to Business and Human Rights." Report of the Special Representative of the Secretary-General for Human Rights and Transnational
Corporations and Other Enterprises, John Ruggie UN Doc.A / HRC / 8/5

Claire METHVEN O'BRIEN. National Action Plans: Current Status and Future Prospects for a New Business and Human Rights Governance Tool // Business and Human Rights Journal. 2016. - Vol. 1:1. - p. 117-125.

Daniel AUGENSTEIN, Mark DAWSON, Pierre THIELBÖRGER. The UNGPs in the European Union: The Open Coordination of Business and Human Rights? //Business and Human Rights Journal - 2018.- Vol. 3:1. - pp. 122

Bauman-Pauly D. Business and Human Rights. From Principles to Practice / D. Baumann-Pauly, J. Nolan. - Taylor and Francis: Routledge, 2017 - 602 p.

Commission (EC) 'A Renewed EU Strategy 2011-14 for Corporate Social Responsibility' COM (2011) 681 final, 25 October 2011.

Declaration of the Committee of Ministers on the UN Guiding Principles 
on business and human rights (16 April 2014)

Government of the Republic of Lithuania, 'Lithuania's Action Plan on the Implementation of the United Nations Guiding Principles on Business and Human Rights' (2015).

Government of Finland, Ministry of Employment and Economy, 'National Action Plan for the Implementation of the UN Guiding Principles on Business and Human Rights' (2014).

Government of Denmark, 'Danish National Action Plan: Implementation of the UN Guiding Principles on Business and Human Rights' (2014).

Government of the Netherlands, Ministry of Foreign Affairs, 'National Action Plan on Business and Human Rights' (2013).

Government of the United Kingdom, Foreign \& Commonwealth Office, 'Good Business: Implementing the UN Guiding Principles on Business and Human Rights' (2013).
Guidance on National Action Plans on Business and Human Rights - UN Working Group on Business and Human Rights, version 1.0, December 2014.

National Action Plans on Business and Human Rights. A Toolkit for the Development, Implementation, and Review of State Commitments to Business and Human Rights Frameworks - DIHR, ICAR, June 2014.

Case of Eweida and Others v. the United Kingdom 27/05/2013, ECHR;

Case of Fadeyeva v. Russia 30/11/2005, ECHR;

Case of Lopez Ostra v. Spain 9/12/1994, ECHR;

Case of Barbalescu v. Romania 12/1/2016, ECHR;

Case of Magyar Tartalomszolgáltatók Egyesülete and Index .hu Zrt. v Hungary 2/5/2016, ECHR;

Case of Rantsev v Cyprus and Russia 10/5/2010, ECHR;

Case of Yershova vs Russia 04/10/2010, ECHR; 
Natalia Zotova. Who and how is

$\underline{\text { national-action-plans-on-business- }}$

human rights

discriminated in Russia against when hiring [electronic resource] // URL https://www.bbc.com/russian/features$\underline{44727766}$

16 major data vendors [electronic resource] // dummies. A Wiley Brand URL:

https://www.dummies.com/programmin g/big-data/16-major-data-vendors/

The ILV spoke about the leaders in violations in the processing of personal data [electronic resource] // URL: https://ria.ru/20190220/1551152806.ht $\underline{\mathrm{ml}}$

Global Business Initiative [electronic resource] // URL: http://www.globalbusiness-initiative.org/wpcontent/uploads/2016/11/NAPs-

Statement-Nov-2016.pdf

New recommendations published on National Action Plans on Business \& Human Rights [electronic resource] // URL:

http://corporatejustice.org/news/15new-recommendations-published-on-

National Action Plans on Business and Human Rights [electronic resource] // URL: https://globalnaps.org/country/ Universal Declaration of Human Rights of December 10, 1948

International Covenant on Civil and Political Rights of December 19, 1966 International Covenant on Economic, Social and Cultural Rights of December 16,1966

ILO Declaration on Fundamental Principles in the World of Work and Mechanism for its Implementation of 18 June 1998

Recommendation CM / Rec (2016) on Human Rights and Business

TASS. The explosions at the plant in Dzerzhinsk occurred in the polymer workshop [electronic resource] // URL: https:

tass.ru/proisshestviya/6498247?utm_so urce $=$ twitter.com \& utm_medium = social \& utm_campaign = smm_social_share 
Periódico do Núcleo de Estudos e Pesquisas sobre Gênero e Direito

Centro de Ciências Jurídicas - Universidade Federal da Paraíba

V. 8 - N 06 - Ano 2019 - Special Edition

ISSN | 2179-7137 | http://periodicos.ufpb.br/ojs2/index.php/ged/index

416

TASS. The authorities of the Nizhny

Novgorod region specified the number

of victims of the explosions in

Dzerzhinsk [electronic resource] // URL:

https://tass.ru/proisshestviya/6498912 